\title{
Determination of Hazard in Captive Hotel
}

\author{
Zuraini Jusoh, Noristisarah Abd Shattar, \\ Hayati Adilin Mohd Abd Majid, Nur Dalila Adenan
}

Universiti Teknologi MARA Terengganu, Dungun, 23000 Malaysia

zuraini338@tganu.uitm.edu.my; noris590@tganu.uitm.edu.my; hayati2959@tganu.uitm.edu.my; dalilaadenan@tganu.uitm.edu.my

\begin{abstract}
This study is to identify the critical risk in cleaning process at the laundry area by using SemiQuantitative Risk Assessment Matrix. In the identification of hazard, observation at the workplace, semistructure interviewed four workers who are an expert in the respective area and reviewed for publication report from authorities' bodies used as an input in risk assessment. The possibility of fingers caught into the flatwork iron (risk value: 9 ) has been identified the most critical risk. The appropriate risk control was isolation, engineering controls, administrative controls and personal protective equipment. This study may help employer be more proactive in ensuring the safety and health of workers.

Keywords: Semi-Quantitative Risk Assessment, Hazard, Risk Control, Captive Hotel

eISSN 2398-4279 @ 2018. The Authors. Published for AMER ABRA cE-Bs by e-International Publishing House, Ltd., UK. This is an open access article under the CC BY-NC-ND license (http://creativecommons.org/licenses/bync-nd/4.0/). Peer-review under responsibility of AMER (Association of Malaysian Environment-Behaviour Researchers), ABRA (Association of Behavioural Researchers on Asians) and cE-Bs (Centre for EnvironmentBehaviour Studies), Faculty of Architecture, Planning \& Surveying, Universiti Teknologi MARA, Malaysia.

DOI: https://doi.org/10.21834/ajqol.v3i10.96
\end{abstract}




\subsection{Introduction}

In hospitality management school, the training hotel or captive hotel was established to offer training facilities using the latest technology and equipment to the students. Indirectly, it can meet the needs of students who are balanced in theory and practical. Through this way, students can conduct in-house training to familiarize themselves with the actual situation in the hotel industry. For a selected group of programs, however, the placement occurs in the related hospitality facility, described as "captive hotel". It is more commonly known as the hotel that provides practical training for all students before graduation. The objective of industrial training is to give early exposure to the students before they are captivating to the real working environment later. Hence, the hotel management program in Europe has succeeded in making the hotel as part of their curriculum.

In the workplace, the risk assessment is conducted to identify the hazards that require more attention, sources, and effort to determine the risk level of each hazard. Alexander (2000) has stretched out the scope of the term "risk" to describe it as not only a hazard but as an unsafe practice. It is a danger that capable of being insured or a statistical probability. Despite, according to Jamelia (2013), risk management is quite new to the hospitality industry. In recent times, little major hotel business had a department committed only to risk management. Today, while some companies do not have a corporate person designated as a risk manager, most firms at least perform the various functional aspects of risk management.

The objectives of this study are to identify the critical risk in cleaning process among workers in the laundry area by using the Semi-Quantitative Risk Assessment Matrix. The risk assessment has been carried out in one of the captive hotels in Terengganu, Malaysia with a total staff of 83 people, consisting of 43 permanent workers, 28 daily workers, and 12 temporary staff. It has started operating since the year 2000 , offering some service businesses such as accommodation, restaurants, event management, catering, and laundry.

Based on the risk assessment its shows that the laundry activities is exposed to the hazard because the use of a high-powered machine. Laundry room have become an essential in today's hotel services. It should be realized that there are many operations in the hotel, which involve the use of chemical and hazardous material such as Dry-Cleaning Machine, LPG and HSD storage, plating and polishing. This lead to the significant hazard associated with hotel operations. This study may help in preventing and reducing exposure of risk to the worker in the workplace.

\subsection{Literature Review}

As posted by Stephen and Kenneth (1994), the most important matter in hotel management education is ensuring the purpose of classroom learning experiences to real management situations. To make sure that students have the necessary practical practice, almost every hospitality management school or program requires some form of practicum or internship.

Risk assessments have by tradition been based on the identification of hazards in the working environment (Lind et al., 2008). Hazard is the cause or circumstances that have the potential to cause injury or illness to humans, property damage, and pollution to the 
environment or a combination of all (NIOSH, 2005). The term "hazard" is indicating as an incident that could cause injury (British Standards Institution, 2004). Hazards are the cause of potential harm to human health, property or environment, which may, under certain conditions, lead to accidents (Lind et al., 2008).

\subsection{Methodology}

\section{Identification of Hazard}

Hazard identification can be seen from the aspect of unsafe employee behavior, the machinery design, chemicals use, methods of work being done and working environment (NIOSH, 2005). Usually, hazard identification, estimation of exposure, and acceptability of the risk (British Standards Institution, 2004) can be identified by risk assessment because they are serve as a basis for controlling an insufferable hazard.

Identification of hazard for this cleaning process had been done by observation in the workplace, semi-structured interview with the four key informers who are an expert in the area and reviewing the publications including reports from law enforcement agencies. This small sample size is supported by Crouch and McKenzi (2006), who said that the sample is determined by the basic logic of the study. This view is an agreement by Patton (2002) who said that in qualitative research, the size of the sample is driven by the purpose of the study. This method has been applied to the study of Ali (2011) who only have four hotel managers counted as the sample of the study. Hence, expert voices on sampling and cases in qualitative research offer guidance on the practical issues to take into account when conducting research projects.

The observations had been carried out during working hours to identify the hazard and exposure through the flow of material, operation facilities, the process, the employee work patterns and contamination or working environment. During the observations in the workplace, a total of four employees were interviewed using a semi-structured interview to obtain information related to the identification of hazard that have occurred and that may occur.

Department of Occupational Safety and Health (DOSH), State Health Department and Fire and Rescue Department reported a chemical substance is the most important things that need immediate action. This is because the wide use of the chemical substances in the laundry for cleaning purposes, providing working attire and personal protective equipment. There are several publications stating that workers who carry out the cleaning process are exposed to a certain hazard. One of the hazards is the mechanical hazard, such as hit or fall due to the layout and physical structure in the laundry area. The range of equipment that can be found in the laundry rooms consists of the folding machine, flatwork ironers, pressers, dry cleaning machines, washers, and dryers. Other hazards include the chemical hazard use in a cleaning process. The ergonomic hazards caused by repetitive work during peak hours such as putting the linen into the washing machine or the dryer and during folding. According to Mohammad (2009), laundries in hotel services are places where clothes and linen are 
washed and ironed. Dryers have the entire basis element that could potentially start a fire such as heat, fuel, and oxygen. Besides, most of the time, the dryer will cause the hazard in the laundry rooms because the person uses the dryers are not regularly concern about the danger that might occur during the drying session.

\section{Risk Assessment}

The risk assessment for the hotel laundry involves seven steps of cleaning process. It begins with the collection of various types of linen into the linen laundry cart follow the separation of linen, based on the fabric material types. Each type of linen needs to be clean separately with different temperatures for drying. It takes between 45 minutes to an hour to be cleaned depending on the load of the washing machines while heavy load will require a longer cleaning period. Then cleaning process continue with drying activities using a dryer machine, and it takes 10 to 30 minutes. Next is ironing activities either using the flatwork ironer or conventional electric iron. The flatwork ironers are applied to any flat linen such as bed sheets, tablecloths, napkins and others while the conventional electric iron is commonly used to the uneven cloth such as garments with accessories. After ironing, each linen will be folded and stored in the proper area before being handed over to the customer or for the use of hotel operations.

The risk assessment method used is Semi-Quantitative Risk Assessment for the quantitative used to differentiate levels of severity and likelihood. Based on Wijeratne et. al., (2014) a recent study has shown, two semi-quantitative risk assessment methods for occupational risk assessment are acknowledged in the literature. The first by Papadakis and Chalkidou (2008), is based on risk matrices with two dimensions, namely, the frequency of occurrence of an accident and the severity of its consequences. Wijeratne et. al., (2014) supported that semi-quantitative analysis is the most preferred technique of stating the risk in the industry. Hence, the risk calculator and the semi-quantitative risk rating matrix can be identified as the most preferred methods for risk analysis.

Semi-Quantitative Risk Assessment Method using risk equation as below (NIOSH, 2005):

Risk $(\mathrm{RV})=$ Severity $(\mathrm{S}) \times$ Likelihood $(\mathrm{L})$

Severity is determined based on injury to health, damage to property and environmental damage. Level and value of severity used in the risk assessment are shown in Table 1 (DOSH, 2008). While the likelihood is based on the observation conducted to obtain information on individual hazard occurs. Levels and value of the likelihood used in the risk assessment are shown in Table 2 (DOSH, 2008). 
Table 1. Levels, Consequences and Severity Value

\begin{tabular}{|lll|}
\hline $\begin{array}{l}\text { Level } \begin{array}{l}\text { Severity } \\
\text { Disaster }\end{array} \\
\text { Fatality }\end{array}$ & $\begin{array}{l}\text { Consequences deaths, property damage and } \\
\text { production cannot be recovered } \\
\text { Approximately one death, damage to } \\
\text { property if the hazard occurs }\end{array}$ & $\begin{array}{l}\text { Severity } \\
\text { Value }\end{array}$ \\
$\begin{array}{l}\text { Severe Injuries } \\
\text { Minor Injuries }\end{array}$ & $\begin{array}{l}\text { Non-fatal injury, permanent disability } \\
\text { Cause disability but not permanent injury }\end{array}$ & 3 \\
$\begin{array}{l}\text { Negligible } \\
\text { injuries }\end{array}$ & $\begin{array}{l}\text { Minimal bruises, wounds, injury needs first } \\
\text { aid treatment }\end{array}$ & 1 \\
\hline
\end{tabular}

Table 2. Levels, Frequency and Value of Likelihood

\begin{tabular}{|lll|}
\hline Level of & Frequency & Likelihood \\
Likelihood & Value \\
Most likely & Most likely to occur & 5 \\
Likely & May occur and not unusual & 4 \\
Expected & $\begin{array}{l}\text { May occur in the future } \\
\text { Rarely }\end{array}$ & 3 \\
Unknown to occur after & 2 \\
Unexpected & $\begin{array}{l}\text { several years } \\
\text { Practically impossible and } \\
\text { never happened }\end{array}$ & 1 \\
\hline
\end{tabular}

To determine whether the risk value is low, medium or high are based on the SemiQuantitative Risk Assessment matrix table. Table 3 shows the Semi-Quantitative Risk Assessment matrix table (DOSH, 2008). Based on Table 3, the green box (RV $=1-4)$ shows the low-risk level, while the yellow box ( $R V=6-10)$ shows that medium risk level and the red box $(R V=11-25)$ showed a high degree of risk level.

Table 3. Semi-Quantitative Risk Assessment Matrix

\begin{tabular}{|l|l|l|l|l|l|l|}
\hline \multicolumn{2}{|l|}{ LIKELIHOOD (L) } & $\begin{array}{l}1 \\
\text { Unexpected }\end{array}$ & $\begin{array}{l}2 \\
\text { Rarely }\end{array}$ & $\begin{array}{l}3 \\
\text { Expected }\end{array}$ & $\begin{array}{l}4 \\
\text { Likely }\end{array}$ & $\begin{array}{l}5 \\
\text { Most } \\
\text { Likely }\end{array}$ \\
\hline SEVERITY & 1 & 1 & 2 & 3 & 4 & 5 \\
\hline $\begin{array}{l}\text { Negligible } \\
\text { injuries }\end{array}$ & 2 & 2 & 4 & 6 & 8 & 10 \\
\hline Minor Injuries & 3 & 3 & 6 & 9 & 12 & 15 \\
\hline Severe Injuries & 3 & 8 & 12 & 16 & 20 \\
\hline $\begin{array}{l}\text { Fatality } \\
\text { Disaster }\end{array}$ & 4 & 4 & 8 & & \\
\hline
\end{tabular}

\subsection{Findings and Discussions}

From the observation, there are a potentially unsafe condition and dangerous act that gives the exposure to the hazard in the hotel laundry. The hazard that has been identified were assessed using Risk Assessment Form as shown in Table 4. The most critical hazard was identified from ironing activities where the highest risk can be explained by $(R V=9)$. The risk 
to fingers or hands, for example, they can be trapped between the moving parts of the flatwork ironer that can cause permanent disability or severed fingers or hand.

The medium risk category $(\mathrm{RV}=8)$ is from washing activities for example struck by the chemical containers that may cause external body injury (i.e. a sprain, torn ligaments or muscles and broken bones). Meanwhile, the lowest risk category $(R V=4)$ are during the collecting, sorting, cleaning, drying, ironing and folding. It can cause a back and upper limb pain because of repetition work. The workers may feel discomforts and body aches. The worker was hit by the linen cart also in lowest risk category ( $R V=4)$, contract back or upper limb pain and burn due to contact with a hot surface. Those may respectively cause the least harm that consists of external body injury; cuts, torn and scratches, discomforts or body aches and burning skins.

Apart from that, all of these risks from the highest, medium and the lowest risk category have resulted in their current risk control as given in Table 4. For example to automatically stop the flatwork ironer if any non-flat object gets into it, to provide training to the workers before start working and paste warning sign on the outer surface of the dryer. These are crucial to prevent the problem from happening continuously. Reveal the results, discuss accordingly, and the implications.

Table 4. Risk Assessment Form

\begin{tabular}{|c|c|c|c|c|c|}
\hline Activities & Hazard & Effect & $\begin{array}{l}\mathrm{Ri} \\
\mathrm{S}\end{array}$ & k & $\begin{array}{l}\text { Value } \\
\text { (RV) }\end{array}$ \\
\hline $\begin{array}{l}\text { Collecting, } \\
\text { sorting, } \\
\text { cleaning, } \\
\text { drying, ironing } \\
\text { and folding }\end{array}$ & $\begin{array}{l}\text { Back and Upper limb } \\
\text { pain }\end{array}$ & $\begin{array}{l}\text { Discomforts and } \\
\text { body aches }\end{array}$ & 1 & 4 & 4 \\
\hline Sorting & $\begin{array}{l}\text { Accidentally knocked } \\
\text { linen cart position at } \\
\text { work path }\end{array}$ & $\begin{array}{l}\text { External body injury; } \\
\text { cuts, torn and } \\
\text { scratches }\end{array}$ & 1 & 4 & 4 \\
\hline Washing & $\begin{array}{l}\text { Struck by the chemical } \\
\text { containers in high } \\
\text { space }\end{array}$ & $\begin{array}{l}\text { External body injury; } \\
\text { sprain, torn } \\
\text { ligaments or } \\
\text { muscles and broken } \\
\text { bones }\end{array}$ & 2 & 4 & 8 \\
\hline Drying & $\begin{array}{l}\text { Burn due to contact } \\
\text { with hot surface of the } \\
\text { outer part of dryer }\end{array}$ & Burn skin & 1 & 4 & 4 \\
\hline Ironing & $\begin{array}{l}\text { Fingers or hands } \\
\text { drawn into trapped } \\
\text { between the moving } \\
\text { flatwork ironer }\end{array}$ & $\begin{array}{l}\text { Permanent } \\
\text { disability; } \\
\text { severed fingers or } \\
\text { hand }\end{array}$ & 3 & 3 & 9 \\
\hline
\end{tabular}

The result shows that the fingers or hands drawn into trapped between the moving parts of the flatwork ironer were the most critical hazard. Trapped in the machine can be categorized as local workplace risk factor. This statement is an agreement with Lind, (2009) who said this 
local workplace risk factor has a plenty of effect to the organization compared to the others risk factor such as organizational risk factor and unsafe acts.

Table 5 shows the recommended appropriate risk control for identified critical hazard based on the hierarchy of risk control. Health professional used a framework called "hierarchy of control" to select ways of dealing with workplace hazard. Selection of control measures is based on the suitability and preference of the hierarchy.

Table 5. Recommended Risk Control

\begin{tabular}{|c|c|c|}
\hline $\begin{array}{l}\text { Risk Control } \\
\end{array}$ & Control Measure & Related Legislation \\
\hline $\begin{array}{l}\text { Isolation } \\
\text { Provide barriers or fencing or } \\
\text { work path }\end{array}$ & $\begin{array}{l}\text { Constructed properly and } \\
\text { securely tied in place the } \\
\text { barriers or fencing. } \\
\text { Passage work path. }\end{array}$ & $\begin{array}{c}\text { OSHA 1994, Section } 17 \text { (1): } \\
\text { Conduct any operations as not } \\
\text { to harm other person as his } \\
\text { employees. } \\
\text { FMA } 1967 \text { (Fencing of } \\
\text { Machinery and Safety) } \\
\text { Regulation 1970, Regulation 4: } \\
\text { Securely fenced any dangerous } \\
\text { part of driven machine, prime } \\
\text { mover and transmission } \\
\text { machinery. }\end{array}$ \\
\hline Provide signage or label & $\begin{array}{c}\text { Signage provides clear } \\
\text { information on hazard warning, } \\
\text { bilingual and color set. } \\
\text { Signage is placed at } \\
\text { conspicuous. }\end{array}$ & $\begin{array}{l}\text { OSHA 1994, Section } 17(2) \text { : } \\
\text { Prescribe information to other } \\
\text { person in which his operations. }\end{array}$ \\
\hline $\begin{array}{l}\text { Engineering Control } \\
\text { Installation of security device }\end{array}$ & $\begin{array}{l}\text { Security device can run } \\
\text { flatwork ironer manually when } \\
\text { workers ready to insert the } \\
\text { linen. }\end{array}$ & $\begin{array}{l}\text { OSHA 1994, Section } 15 \text { (2) } \\
\text { (d): Provision of maintenance in } \\
\text { a safe condition and without } \\
\text { risks, as far as practicable. }\end{array}$ \\
\hline Maintenance activity & $\begin{array}{c}\text { Record and kept well the } \\
\text { maintenance of flatwork ironers. } \\
\text { Undertake immediate } \\
\text { action to repair if breakdown } \\
\text { occurs. Identified the cause of } \\
\text { breakdown and recorded as a } \\
\text { preventive measure. } \\
\text { Retest after repairing work } \\
\text { to ensure proper functioning. }\end{array}$ & \\
\hline $\begin{array}{c}\text { Administrative Control } \\
\text { Review safe work procedures }\end{array}$ & $\begin{array}{l}\text { Safe work procedures need } \\
\text { to be revised to ensure the } \\
\text { relevancy. }\end{array}$ & $\begin{array}{l}\text { OSHA 1994, Section } 15 \text { (2) } \\
\text { (c): Provision of information, } \\
\text { instruction, training and } \\
\text { supervision as far as practicable. }\end{array}$ \\
\hline Training & Periodic training as & \\
\hline
\end{tabular}




\begin{tabular}{|c|c|c|}
\hline & $\begin{array}{l}\text { suitability to workers' need and } \\
\text { job demand: } \\
\text { Education of mechanical } \\
\text { hazard } \\
\text { Safety training } \\
\text { First aid training } \\
\end{array}$ & \\
\hline Toolbox Meeting & $\begin{array}{l}\text { Hold tool box meeting in } \\
\text { every shift of work to provide } \\
\text { updates and reminders on } \\
\text { hazard during work hours } \\
\text { before they are discharge from } \\
\text { their duties. }\end{array}$ & \\
\hline Non-Verbal Communication & $\begin{array}{c}\text { Use a publication such as } \\
\text { bulletins, newsletter to share } \\
\text { and inform the safety and health } \\
\text { matters }\end{array}$ & \\
\hline Job Hazard Analysis (JSA) & $\begin{array}{c}\text { Prepare Job Hazard } \\
\text { Analysis with job information } \\
\text { and faulty action can be } \\
\text { occuring for any risky job. }\end{array}$ & $\begin{array}{l}\text { OSHA 1994, Safety and } \\
\text { Health Committee Regulation } \\
\text { 1996, Regulation 19(1): The } \\
\text { employer shall consult the } \\
\text { committee to prepare the rules } \\
\text { or procedures to guide workers } \\
\text { in daily job activities. }\end{array}$ \\
\hline Meeting & $\begin{array}{l}\text { Arrange meeting at least } \\
\text { once in every three months for } \\
\text { employees and employers to } \\
\text { discuss any safety and health } \\
\text { issue. }\end{array}$ & $\begin{array}{l}\text { OSHA 1994, Safety and } \\
\text { Health Committee Regulation } \\
\text { 1996, Regulation 21: Frequency } \\
\text { of meeting at least once in every } \\
\text { three months. }\end{array}$ \\
\hline Inspection & $\begin{array}{l}\text { Regularly inspection at } \\
\text { least once in every three } \\
\text { months to take an corrective } \\
\text { action on safety and health } \\
\text { issue at the workplace. }\end{array}$ & $\begin{array}{c}\text { OSHA 1994, Safety and } \\
\text { Health Committee Regulation } \\
\text { 1996, Regulation } 16: \text { The } \\
\text { committee is required to conduct } \\
\text { workplace inspections. }\end{array}$ \\
\hline $\begin{array}{l}\text { Personal Protective } \\
\text { Equipment (PPE) }\end{array}$ & $\begin{array}{l}\text { Record the distribution of } \\
\text { PPE to the workers. } \\
\text { Provide training to ensure } \\
\text { the compliance of workers in } \\
\text { proper wearing the PPE. } \\
\text { Ensure an adequate supply } \\
\text { of PPE and readily available to } \\
\text { workers. }\end{array}$ & $\begin{array}{c}\text { OSHA 1994, Section 15 (2) } \\
\text { (e):Provision and maintenance } \\
\text { of a working environment with } \\
\text { an adequate welfare facilities. } \\
\& \\
\text { FMA } 1967 \text { (Safety, Health } \\
\text { and Welfare) Regulation 1970, } \\
\text { Regulation } 32 \text { (a) (i): Working } \\
\text { clothes shall be of good fit and } \\
\text { no loose. }\end{array}$ \\
\hline
\end{tabular}

Based on Butch (2003), by understanding the hierarchy, the worker at laundry or in the industry can prevent exposure to the hazard because the purpose of risk control is to prevent and minimize the exposure of the hazard. There are six steps of risk control in the hierarchy of control that starts with the elimination, followed by a substitute, isolation, engineering control, administrative control, and personal protective equipment. Appropriate control 
measures began with the isolation, followed by engineering control, administrative control, and personal protective equipment. Elimination of ironing activities is unsuitable because this is one of the required activities in the hotel laundry service. Substitute the flatwork ironer to another machine also seems inappropriate because it involves high costs.

In every of risk control, there is a control measure. Control measure is a suggestion to a specific action which can be done to eliminate the risk or to minimize the risk. The control measure was suggested accordingly to the related legislation.

\subsection{Conclusion}

From the recommendations, there are some benefits that can be obtained when performing the risk assessment. Organization can set a risk management standard based on acceptable safe practices and legal requirement. It also becomes a step towards complying the Occupational Safety and Health Act as a practice and fulfill the human rights. The safe environment can provide comfort to workers in producing a high-quality service and meet the needs of customers. The findings presented in this study may facilitate the hotel management in identifying and raising awareness of their workers when operating the equipment or machinery that could potentially cause injury to them. Thus, the rate of injuries at the workplace can be reduced. Also "Zero Incident" can be realized. If the causes of the accident can be identified, the appropriate control measures can be implemented to prevent accidents from occurring or repeated. Indirectly, it can control the losses that will be experienced by the organization.

This study has been implemented only in one hotel, as a case study and it is recommended to study on varieties of the hotel for future research. It is also important to give more shed light for risk assessment and safety environment in the hotel industry. Apart from that, it is also meaningful if it can be extent to the new area of hotel environment such as kitchen and restaurant. Other methods also can be used to analyze the hazard such as Job Hazard Analysis (JHA), Hazards and Operability Studies (HAZOP) and Fault Tree Analysis.

\section{References}

Alexander, K. (2000), Facilities Management: Theory and Practice. (4th ed.). New York: Taylor and Francis, (Chapter 7).

Ali, Y. (2011). The Impact of ICT in the Eyes of Hotel Managers (Cyprus). (Master's Dissertation, Sodernton University). Retrieved from http://sh.diva-portal.org/smash/get/diva2:479447/FULLTEXT01 .pdf

Baker, S.E. and Edward, R. (n.d), How many qualitative interviews is enough?. National Centre for Research Methods Review Paper. Retrieved from http://eprints.ncrm.ac.uk/2273/4/how_many_interviews.pdf

British Standards Institution (2004), BS8800: Occupational Health and Safety Management Systems - Guide, British Standards Institution, London.

Butch de Castro, A.B. (2003). Hierarchy of Controls: Providing a framework for addressing workplace hazards. AJN, American Journal of Nursing: 103, 12-104. 
Crouch, M. and McKenzie, H. (2006). The logic of small samples in interview-based qualitative research qualitative research. Social Science Information. Vol 45(4), 483-499.

DOSH, Department of Occupational Safety and Health (2008), Guideline Hazard Identification, Risk Assessment and Risk Control, DP 127/789/4-47. ISBN 978-983-2014-62-1. Ministry of Human Resource, Malaysia.

Ferdinand F. Fiurnies (2007). Why Employees Don't Do What They're Supposed To Do: and What To Do About It (1st ed.). New York: McGraw-Hill Companies

Jamelia S. (2003). Tourists' Perceived Risks Toward Overt Safety Measures. Journal of Hospitality \& Tourism Research, 37,199-216.

Lind, S. (2008). Types and sources of fatal and severe non-fatal accidents in industrial maintenance. International Journal of Industrial Ergonomics, 38, 11-12.

Lind, S., Nenonen, S. and Rahnasto, J.K. (2008). Safety risk assessment in industrial maintenance, Journal of Quality in Maintenance Engineering, 14(2), 205-217.

Malaysia Law Factory and Machinery Act 1967 International Law Book Services. Malaysia.

Malaysia Law Occupational Safety \& Helath 1994 International Law Book Services. Malaysia

Milczarek, M. and Kosk-Bienko, J. (2010). Maintenance and Occupational Safety and Health: A Statistical Picture, European risk observatory EA-OSHA, Luxembourg.

Mohammad A. Hassanain, (2009). Approaches to qualitative fire safety risk assessment in hotel facilities. Structural Survey, 27(4), 287-300.

NIOSH 2005 Training Manual for Safety \& Health Officer Certificate Programme. Malaysia.

Papadakis, G.A. and Chalkidou, A.A. (2008). The exposure-damage approach in the quantification of occupational risk in workplaces involving dangerous substances. Safety Science, 46 (6), 972-991.

Papadopoulos, G., Georgiadou, P., Papazoglou, C. and Michaliou, K. (2010). Occupational and public health and safety in a changing work environment: An integrated approach for risk assessment and prevention. Safety Science, 48 (8), 943-946.

Patton, M. Q. (2002). Qualitative evaluation and research methods, (3rd ed.). Thousand Oaks,. CA: Sage Publications, Inc. Seale, C.

Wijeratne, W.M.P.U., Perera, B.A.K.S., De Silva, L. (2014). Identification and assessment risks in maintenance operations. Built Environment Project and Asset Management, 4 (4), 384-405. 